\title{
Spirit, vulnerability and beauty - a pneumatological exploration
}

NGTT DEEL 55, NR 3 \& 4, 2014

\section{Van den Bosch, D}

University of the Free State

\begin{abstract}
Vulnerability is for most people a problematic concept. However, there are several theological discourses revealing an exciting reinterpretation of vulnerability. The recent attention to vulnerability opens novel and vital perspectives on human life in relation to God. The first part of this article is an overview of constructive Reformed theological proposals that offer a promising hermeneutics of vulnerability. The second part presents an additional constructive proposal: a pneumatological exploration of vulnerability. The pairing of Spirit and vulnerability leads to the understanding that vulnerability is the realm of the Holy Spirit. Notions such as quality, transformation, vulnerability dialectics, beauty and danger turn out to be critical constituents of the bond between Spirit and vulnerability.
\end{abstract}

\section{KEYWORDS}

Holy Spirit, Vulnerability, Beauty, Reformed theology, William Placher, David Jensen, Thomas Reynolds, Kristine Culp

\section{CONTACT DETAILS}

Dr Deborah van den Bosch

Research Fellow Department Systematic Theology, University of the Free State boschheij@gmail.com 


\section{INTRODUCTION}

Often people understand vulnerability as being synonymous with weakness and frailty. The common understanding of vulnerability is that it is a state one does not want to be in, because it implies lack of control, power, vitality and independency. It is not surprising that this negative understanding of vulnerability has led to different strategies of invulnerability. Insurance policies, the building of dykes, having airbags in the car, vitamin pills - these are just a few illustrations of how people try to safeguard themselves against their own vulnerability (see Culp 2010:88).

However, there is a growing body of theological voices that aims at resisting the negative interpretation of vulnerability. These voices introduce an approach to vulnerability that is beyond deficiency and lack of power. According to these voices, vulnerability is so much more than we tend to think. The myth of invulnerability and the illusion of control are being denounced, while new understandings of vulnerability are being explored.

Various disciplines of theology reveal an exciting turn towards the notion of vulnerability. Within theHIV/Aids discourse, for example, theological methodologies have been developed in order to give voice to marginalized and infected people (see West \& Zengele-Nzimande 2006; West 2003, 2004. See also Dube 2002; 2004; and the important contributions of the Circle of Concerned African Women Theologians). The field of disability studies emphasizes the idea that it is objectionable to disqualify physical and mental disability. On the contrary, vulnerability is an essential aspect of theological reflection on the imago Dei (see Eiesland 1994; Reinders 2000; Berinyuu 2004; Yong 2007; Reynolds 2008). And within body theologies discourse, we encounter a high appreciation of the vulnerable body that, contrary to the myth of invulnerability, is seen as the very source of God-talk (see Nelson 1992; Isherwood \& Stuart 1998:11; van Niekerk 2012). And there are other fields of theology that reveal how the notion of vulnerability can spur a particular hermeneutical development; see for example various contributions on empire (Rieger 2001; 2007; Snyman 2011), on interreligious dialogue (Yong 2008; Moyaert 2012), on practical theology (Meylahn 2012), on ecclesiology (Koopman 2008). One might say that the different hermeneutical understanding of vulnerability has not fully surfaced yet, but it is already obvious that it implies a meaningful development for Reformed theologies in a world that normalizes the denial of vulnerability. The various theological voices make us aware that the common definition of vulnerability is the product of the illusion of control, and that a reinterpretation of vulnerability opens fruitful avenues for understanding human life in relation to God. 
In his contribution to Towards the Future of Reformed Theology, William Placher (1999:192-205) refers to the theme of vulnerability as an important topic in Reformed theologies (see also Placher 1994). He contends that the relevance of the theme of vulnerability is closely related to the biblical witness to God of the Bible. When Christian theologians reflect on vulnerability, they are 'only reclaiming their own birth right, for it is just such a God that we encounter in the Bible' (Placher 1999:194).

Like Placher, a number of other Reformed theologians have developed inspiring proposals regarding the understanding of the vulnerability of human life in relation to the biblical God. The constructive theological contributions offer an important kind of hermeneutics of vulnerability. These novel insights carry great weight for Reformed theology because they disclose blind spots in our God-talk and in our ecclesial practices. The value of reconstructing vulnerability is that vulnerability can be recognized as an existential quality in relation with God.

In this article I first turn to some inspiring constructive theological accounts of vulnerability. I will provide a brief overview of the work of William Placher (Narratives of a Vulnerable God, 1994), David Jensen (Graced Vulnerability, 2005), Thomas Reynolds (Vulnerable Communion, 2008) and Kristine Culp (Vulnerability and Glory, 2010).

The brief overview of constructive theologies of vulnerability presents us with an interesting perspective on vulnerability: it is complex and ambiguous. This new perspective transcends the idea of vulnerability as an undesirable condition of creation life. The theological accounts of Placher, Jensen, Reynolds and Culp link the concept of vulnerability to the relational life of the triune God, the vulnerable life of Christ who was crucified and resurrected, human being as carrier of the imago Dei, human life coram Deo. It turns out that vulnerability is a complex and multi-layered concept within Reformed theology.

The brief overview also reveals the absence of pneumatological interpretations of vulnerability. We do find Trinitarian relational perspectives on vulnerability. But where would an exploration of human vulnerability from a pneumatological point of view lead us? I am not proposing to move away from what already has been said about vulnerability from a Christological and Trinitarian perspective, but to offer additional interpretations of vulnerability.

The second part of my contribution will focus on the Holy Spirit in relation to human vulnerability. Starting with a biblical understanding of the vulnerable Spirit, it will transpire that vulnerability can be understood as the realm of the Creator Spirit. The insight that vulnerability and the Holy Spirit are inextricably linked invites questions 
regarding the meaning of vulnerability being the realm of the Spirit. What kind of theological proposal emerges from the connection between Spirit and vulnerability? Is it possible to construct a new perspective on vulnerability when vulnerability and the agency of the Holy Spirit are joined together?

My hypothesis is that the agency of the Holy Spirit leads to an extended hermeneutics of vulnerability. The link between Spirit and vulnerability bestows a particular quality to human vulnerability, because the person of the Holy Spirit is fully involved in the vulnerability of creation. This particular quality turns vulnerability into a nonpassive, dynamic condition of life, because when vulnerability is understood as the realm of the Spirit, then being vulnerable means being involved in the beautification of life. Being vulnerable thus implies a resistance against the myth of control. It also entails a spirited attitude towards life.

This pneumatological exploration is just an exploration, a search for constructive thoughts about the notion of vulnerability in relation to the work of the Holy Spirit. Since the Holy Spirit in Reformed theology is closely related to creation but not (yet) to vulnerable life, it makes sense to concentrate on the agency of the Spirit. My contribution is motivated by the significance of the theme for Reformed theologies in a world in which vulnerability is usually denounced, despite the fact that vulnerability is a given in human existence. The aim is to present existing constructive proposals of vulnerability in Reformed theology, and to consider the agency of the Holy Spirit with regard to vulnerability.

\section{REFORMED VOICES ON VULNERABILITY}

Some Reformed theologians have offered an incentive to theological reflection on vulnerability. Bonhoeffer, ${ }^{1}$ Barth and Moltmann drew attention to the notion of vulnerability by referring to God's strange power as a kind of weakness revealing His love for mankind. They wrote from their own particular experience about a God who suffers with creation because of his love. Liberation theologians presented their own perspective on God's preference for the weak and the vulnerable. And this movement raised theological awareness of notions of weakness, suffering and vulnerability. A novel perspective in God-talk was introduced: God became associated with vulnerability rather than with power and omnipotence.

This association has existential consequences for human life. What does it mean to witness to a vulnerable God who loves vulnerable people? William Placher, David

1 "Christ helps us not by virtue of his omnipotence, but by virtue of his weakness and suffering ... Only the suffering God can help” (Bonhoeffer 1972:360f). 
Jensen, Thomas Reynolds and Kristine Culp developed their views on this question. Below I will offer a brief overview of their invigorating, constructive contributions to vulnerability theologies. I do not attempt to give a complete presentation of the various constructive proposals; the main focus will be on how each approach interprets vulnerability, and how this interpretation is accounted for. This overview provides the constructive background for a pneumatological exploration of vulnerability.

\section{a. William C Placher}

In his book Narratives of a Vulnerable God. Christ, Theology and Scripture (1994) Placher seeks to recover particular interpretations of God by looking at the biblical narratives, especially the gospel stories about Jesus. Placher wants to move away from a generic understanding of God as an all-powerful God who is in charge of everything, because the Scriptures tell a different story of this God. In the biblical narratives God reveals himself as a God who is willing to be vulnerable to pain in the freedom of love. Vulnerability, Placher says, is a perfection of loving freedom (19). It is the willingness to risk pain and suffering. And this loving freedom, this divine willingness to take the risk that his love remains unanswered, presents us with a paradigm for our own life and love: "the kinds of risk that the security of knowing God's love permits, are not just a kind of bonus but part of what it means to be fully human, just as the capacity for vulnerable love without limit is part of what it means to be God" (20).

Placher develops his ideas about the vulnerable God by paying attention to the notion of eternity. The biblical stories witness to a loving God who is faithful even when $\mathrm{He}$ takes the risk of being hurt and rejected. God's faithfulness seems to be at odds with vulnerability, because God's faithfulness may refer to a God who is unchanging and immutable. But Placher's interpretation of time is such that he defines eternity as "a 'time' neither of invulnerable changelessness nor of shifting and unreliable relations but the 'time' where fully vulnerable love can be trustworthy" (45). Speaking of an eternal God implies speaking of God in trinitarian terms, because God's love is about God's being: God is a community of equals united in mutual love (73), and this perichoretic love is a love that dares to risk being vulnerable. After all, the biblical stories tell about Jesus Christ, the vulnerable God who can most be with us in our sufferings.

In the final part of his book Placher explores what it means for Christian communities to worship the triune, vulnerable God. He translates the meaning of divine vulnerability into various practices for believers: being the church of a vulnerable God means that believers open themselves to outsiders and strangers of 
the world on the basis of biblical stories about the crucified Christ. By holding on to the narratives and the sacraments, Christians make known the vulnerable God. Focusing on the biblical vulnerability narratives has also implications for the roles that believers assume in academic settings and in the wider social contexts where they work and live: Christians have to become outsiders themselves (178) and move beyond their comfort zone to be made whole by the vulnerable God.

\section{b. David H Jensen}

In his book Graced Vulnerability. A Theology of Childhood (2005) Jensen develops a theological perspective on childhood. He convincingly shows that such a theology of childhood includes practices of vulnerability. Jensen starts with uncovering a blind spot of Christian theology: while the birth of the divine child is granted a central place in Christian faith, theological attention to children is more or less absent. Jensen's advocacy theology draws attention to the vulnerable, broken, and downtrodden in this world (xiv), and aims at representing the children neglected by theology.

Jensen starts off with the biblical covenantal perspective and with Jesus' attitude towards children, and he claims that children are included in the covenant. This means that we should be paying special attention to the meaning of vulnerability in light of the relationship with the covenantal God. With Jensen, the theological meaning of vulnerability is anchored in the imago Dei. The raison dêtre of every person is warranted on the basis of the belief that every human being is uniquely created in the image of God. But the imago Dei should not be interpreted as a common denominator of human characteristics (like rationality, power of dominion, morality, capacity for love, possession of an eternal soul), because the image of God is not "a mold that shapes human life in uniformity" (14). On the basis of the biblical text in Genesis 1:27, Jensen points out that there is difference in the image of God: 'male and female he created them'. When one chooses to understand difference as the core idea of the imago Dei, one sees that difference implies openness to others and thus to vulnerability. Jensen contends that openness and vulnerability are incorporated in the image of God: "The God of the Bible is not a monad enclosed upon itself, but a God who becomes vulnerable in relation to others, who calls us to live in vulnerability with other" (15). So, God self is the source of differences, and thus of openness and vulnerability. At distinctive moments in history, this God of difference and openness reveals himself as a God with a preference for vulnerability. The covenantal relationship with Israel, the divine revelation in vulnerable flesh, Jesus' acknowledgment of vulnerable and marginalized people, the strange vulnerability of the cross and of the resurrection, the communal life of the triune God - in multiple 
ways the biblical God reveals a God who opens himself to others, thus a God who is inclined to vulnerability.

After having constructed a theological meaning of vulnerability (relationships, differences and openness), Jensen points out that childhood is one very essential dimension of the vulnerable, related existence into which human beings are called. His theological perspective on childhood has particular implications for believers witnessing to a vulnerable God. Who seeks shelter in the covenant with God, will come to understand baptism as a communal expression of vulnerability and resistance to violence against children. Peace-making and nonviolence ought to be typical traits of the baptismal practice of vulnerability. A church community could be a sanctuary for children as well, for it is God's space for physical safety and a harbour for emotional and spiritual growth (113). And prayer is a crucial locus of ecclesial practices of vulnerability, since prayer is a relational act that makes us open and vulnerable to God and to the world. Jensen's vulnerability ecclesiology approaches children as full members of the covenant community, and places them in the presence of the vulnerable God who prefers differences and openness.

\section{c. Thomas E Reynolds}

In his book Vulnerable Communion. A Theology of Disability and Hospitality (2008) Reynolds offers a theological account of disability. His aim is to reach novel understandings of disability in order to develop counter practices that reveal abundant hospitality. Reynolds' personal experiences with raising and loving a son with disabilities form a delicate part of this exploration.

Reynolds' careful rethinking of human disability starts with critiquing the ruling 'cult of normalcy'. This cult of normalcy refers to the social processes and relationships people enter when they seek a place of welcome and acknowledgment. Human beings are involved in social contexts, such as school, sports, employment, family, friendship, and these social contexts cultivate their own performance expectations and criteria of value measurement. This means that ideas about what is normal are made desirable, and that they are enforced in public venues as the standard (60). Reynolds emphasizes that there is a standardizing power underneath a society's conventions and the norms that remain unquestioned. This standardizing power carries the tyranny of normalcy, and assigns aberrancy to what is perceived as different, disable, abnormal, the other.

Reynolds suggests a counter discourse by painting the contours of an anthropology that is based upon the understanding that human beings are relational beings. Human beings are incomplete, vulnerable, and they need others to become complete. 
In being relational by definition, human beings are vulnerable. We are open to and in need of relationships and community. Human vulnerability is thus a testimony to the fact that our nature involves receiving our existence from each other (106). The aim of centralizing vulnerability and disability is not to valorise vulnerability nor to trivialize it as an instructive tool for those who perceive themselves as healthy, but to reach the understanding that each person is vulnerable and open to being wounded. Privileging disability, Reynolds says, calls us to responsibility as agents capable of loving and welcoming others on the basis of our human vulnerability.

Vulnerability, thus, must be protected against the tyranny of normalcy, and must be interpreted as an acknowledgment of weakness and limitation that is made concrete in relations of mutual openness and dependence. This perspective draws Reynolds into a religious space of orientation. This is where his theological account begins. Reynolds forges a path into a theology of disability by understanding life as a gift. This is how the sense of God arises in human life: God is the creator of life, and 'to exist is good, a grace received' (139). Recognizing one another's vulnerability and value is embracing this gift of life. Creation opens up to God, and senses an extraordinary possibility in vulnerable ordinariness. God's relationship with creation reveals God's own vulnerability: "As God becomes relationally open to God's gift of creation and lovingly embraces creatures as distinct and valuable beings, God shows vulnerability" (165). In other words, vulnerability and disability are part of the world God loves. Particularly in the light of creation theology, Reynolds warns that one should be mindful not to view vulnerability and disability as tragedy, because that is the song of the cult of normalcy, which might even be called "sinful" (169). He therefore proposes to reconsider the imago Dei as imitatio Dei, for God is a vulnerable, creative, relational and available God (179). Created in God's image, human beings are gifted with the capacity to respect, be faithful to, and show compassion to others.

Jesus Christ is the icon of a vulnerable God (197). In being crucified and in being resurrected, Jesus overturns the established powers and principalities, and He reveals the transformative power of love by redeeming us from our fear-based anxiety of the abnormal, the vulnerable and the disabled. This is what Reynolds calls 'reversing disability's disability'. In Christ, human beings are brought into relational wholeness with one another.

Reynolds started his constructive theology of disability and hospitality because he experienced painful rejection of his son with disabilities within the church community. His aim was to rethink human community into communities of abundant hospitality, and along this line he closes his book: 'the nature of this creative-redemptive love fosters a recognition and acceptance of human vulnerability 
and disability as bearing the image of God. And it does so in a gesture of trusting welcome. The moral thrust of Christian community has its origin here' (211).

\section{d. Kristine A Culp}

In her book Vulnerability and Glory. A Theological Account (2010) Culp presents the contours of the meaning of human vulnerability before God. She starts off with Paul's reference to human life as earthen vessels that contain a glorious divine treasure: the human being is vulnerable, but capable of bearing glory. With Augustine, Luther and Calvin, Culp explores the relation between human fallibility and divine power, between corruption and transformation. She taps into a variety of sources of her theological account of vulnerability, and she contends that vulnerability is much more than a reference to deficiency or lack of strength. Culp makes a surprising move by untangling vulnerability from the idiom of risk assessment and devastation. Culp does not deny the daily reality of this world, nor does she downplay suffering or ignore evil. She just refuses to deliver the concept of vulnerability to a simple understanding of vulnerability. Culp rejects the general contemporary interpretation of vulnerability as a condition to be overcome. Vulnerability is not just something that refers to damage and threats. Rather, it is an ambivalent and multi-layered concept that embraces both devastation and glory.

Culp's theological account of vulnerability is actually an account of life before God. Human life is a gift of the living God. This gift turns human life into life that is not only susceptible to harm, but also to bearing glory. This is what vulnerability means: that human life by definition embraces both ill and well, both rejection and welcome. In other words, being alive implies that one is susceptible to being "changed in ways that may be destructive or transformative" (95).

In the second and the third part of Vulnerability and Glory, Culp addresses the theological and practical implications of vulnerable humans and creatures coram Deo. She engages two Protestant marks of the church to elaborate on the meaning of being vulnerable, of being involved in transformation towards the glory of God, which means that one opens oneself to participating life with and for other in the sight of God. These Protestant marks are the call to resist idolatry and inhumanity, and the journey of delight and gratitude. Culp indicates that "in a world marked by suffering and in which creatures are vulnerable to devastation and transformation, such testimony and resistance and such delight and gratitude may provide a baseline for living with others before God" (130). 


\section{e. Evaluation}

How do Placher, Jensen, Reynolds and Culp define vulnerability in their contributions? This brief evaluation will show that vulnerability is a complex and multifaceted concept.

Placher defines vulnerability as the willingness to risk pain on the basis of love. He positions vulnerability within a Trinitarian framework: it is divine perichoretic love that is the source of vulnerability, and Jesus Christ reveals how the biblical God chooses to become vulnerable out of love. Placher's important contribution to the theme of vulnerability is the focus on the biblical narratives of vulnerability. These narratives reveal that vulnerability is the crux in the relationship between God and mankind.

Unlike Placher, Jensen does not explicitly define vulnerability. In Jensen's approach, vulnerability is the opposite of violence and oppression. It receives a meaningful interpretation when it is linked to differences and to openness towards one another in order to celebrate differences. Being vulnerable implies openness and tolerance. Like Placher, Jensen understands vulnerability as related to the trinity: the communal life of the triune God means that God's being is open and vulnerable. God's vulnerability is found in the brokenness of Jesus Christ, and in the story of God's covenant with his people. Jensen then shifts his focus from the divine image of vulnerability to vulnerability in society and church, and he shows how God's vulnerability changes our understanding of children (and other vulnerable groups) in ways never seen before in church history.

Reynolds does not interpret vulnerability within a Trinitarian frame, as Placher and Jensen do. Instead, Reynolds develops his ideas about vulnerability from a sociological perspective: vulnerability is part of disability discourse and of the abject cult of normalcy. From the reflection on and the experience with disability, Reynolds moves to a theology of disability that hinges on the idea that disability is not something less than normal. In theological terms, Reynolds approach to vulnerability is quite plain. He defines vulnerability within the frame of creation theology: God creates difference, and God self is vulnerable in his relationship with creation. In this light, the cult of normalcy can be called sinful, and the redemption of Christ implies the turning over of the tyrannical cult of normalcy. Human being, created in the image of God, is called to imitate God (imago Dei as imitatio Dei) by resisting the cult of normalcy and by releasing transformative power into creation. For the Christian community this transformative power means welcoming every person (in particular those who are abandoned by the cult of normalcy). Vulnerability and 
disability, then, are notions interconnected with Christ-like hospitality in church and society.

Culp defines vulnerability as complex and ambivalent. She leaves traditional ideas about vulnerability as synonymous with damage and with being wounded behind by creating space for a concept of vulnerability as a dynamic condition of human life. By definition life is vulnerable, meaning that a person is susceptible for devastation, suffering and grief; but a person is also susceptible for growth, change and meaning. Being vulnerable is being open to wounds and to healing. In addition to the ambivalence of vulnerability, Culp emphasizes that vulnerability is a condition coram Deo. Before the face of God there is room for damage and for transformation; God's presence embraces the dynamics of human life. In theological terms, Culp's approach to vulnerability focuses mainly on the glory of God. Vulnerability is related to daily life in practices such as resistance to idolatry and inhumanity, and the expression of gratitude and joy for the good things in life. Culp's theological move is that vulnerability is closely related to the glory of God, and that it is a dynamic testimony of faith.

In summary it can be said that the concept of vulnerability emerges in different ways in the various constructive proposals. Vulnerability is associated with the vulnerability in God self (triune community, inner-trinitarian relationships, innerdivine openness). God's own vulnerability is also revealed in the cross of Christ, the icon of the vulnerable God. And God's vulnerability is not separated from the vulnerability of creation. Notions such as imago Dei, imitatio Dei and coram Deo reinforce the relation between divine and human vulnerability. The vulnerability of creation in light of divine vulnerability is further translated in vulnerability as feature of community life and ecclesial practices. Vulnerability is about an ambivalent way of life: it is devastation as well as transformation that can be practiced through sanctification, hospitality, resistance to degradation of life, and thankfulness. All these different aspects of vulnerability reveal that vulnerability is a multi-layered, complex, ambiguous concept.

It is remarkable, however, that in the wide range of colours of vulnerability, the work of the Holy Spirit is not painted in bright colours. What can be said about the Holy Spirit in relation to the theme of vulnerability? Will a pneumatological interpretation of vulnerability bring about further thoughts about human vulnerability? The next part of this contribution is an exploration of the relationship between the Holy Spirit and vulnerability. 


\section{SPIRIT AND VULNERABILITY}

In the following part I will consider the relationship between the Holy Spirit and creation. I will argue that this relationship includes vulnerability, because God's Spirit becomes vulnerable by being involved in creation. The relationship between Spirit and creation is such that vulnerability may be viewed as the realm of the Holy Spirit. Since Jürgen Moltmann is the only Reformed theologian who has addressed the issue of Spirit/creation/vulnerability specifically (in his Spirit of Life), I will briefly describe his ideas here as well.

\section{The vulnerable Spirit}

The Spirit of God is often associated with creation. The Bible opens with the Spirit hovering over the water. The Bible continues with the creation narrative of the Spirit as the life-giving breath of God, and later draws attention to the Spirit as the groaning companion of creation. These biblical perspectives encourage the idea that the Spirit of God specifically embarks on those matters that tie human beings to their created existence.

The Spirit of God is also associated with the vulnerability of creation in such a way that the Spirit's own sensibility and vulnerability surfaces. Biblical texts such as 1 Thessalonians 5:19 ('do not put out the Spirit's fire') and Ephesians 4:30 ('do not grieve the Holy Spirit of God, with whom you were sealed for the day of redemption') show that the Holy Spirit is not an unaffected and invulnerable power that blows wherever the Spirit pleases. In fact, the Spirit of God can even be tested and insulted (Ac 5:9, Heb 10:29). In other words, the Holy Spirit is committed to creation in a personal way. Or, in the words of Eugene Rogers Jr (2005:60): "the Spirit is a Person with an affinity for material things. The Spirit characteristically befriends the body."

The vulnerability of God's Spirit transpires in what the Spirit does. It is reflected in the agency of the Spirit: the Spirit suffers with the suffering, is grieved and quenched, and rejoices when creation rejoices (Moltmann 1992:51). As Romans 8:22-26 shows, the vulnerability of the Spirit has to do with the Spirit's preference for creation. By indwelling in creation, the Spirit bonds with creation, and fully identifies with the vulnerable condition of creation in the sense that the Spirit groans with us and helps us in our weakness (cf. Polkinghorne 2006:181). The Spirit seeks to befriend and to look after God's good creation in such a way that the Spirit self, working on the inside of creation, becomes vulnerable. 


\section{Vulnerability as the realm of the Spirit}

In a fascinating article on the hidden works of the Spirit in the cosmos, John Polkinghorne (2006:179) elaborates on how God is at work within the contingent processes in the world. Polkinghorne's proposal is to be considered in light of the faith and science dialogue. He addresses the idea that God, creator of this world, is involved in the world in such a way that God is not only present in the disrupting, interventionist moments of life, but in the continuous unfolding of history as well. Here Polkinghorne follows the ideas of John V. Taylor (1972:28) who contends that, if there is a creator God at all, He is present in the whole process of life and not only in the gaps of divine intervention. In connection to Taylor's rejection of the interventionist idea of a God who enters when human knowledge fails, Polkinghorne twists the concept of the 'God of the gaps' by suggesting that these gaps should be considered as rather benevolent, because they match very well with the intrinsic features of this world. Polkinghorne proposes to understand the gaps of contingency as gaps that belong to the reality of creation. And these contingent spaces of life form the hiding place of God's Spirit. The 'Spirit of gaps' is present, hidden and veiled, right there in the historically unfolding fruitfulness and in the change and decay that are inescapable features of this world (181). These gaps are the loci of pneumatological involvement with the travail of creation. The gaps of contingency have nothing to do with interrupting power exercises of the Spirit, but they constitute the realm where the Spirit works on the inside of creation, keeping the fruitfulness and contingency, the order and the disorder of human life closely together. In other words, in the gaps of our contingent, creaturely life the Spirit is at work, dissolving our self-constructed ideas of infinity and restoring our longing for fullness.

The contingency of creation is where the Spirit resides - in those places and moments where human beings have to deal with unforeseen events and uncertainties. The realm of the Holy Spirit may thus be seen as the sphere of open spaces where human vulnerability becomes most palpable. In a sense the presence of the Holy Spirit holds creation's goodness and vulnerability together. Under the reign of the Spirit we come to see that God's creation is simultaneously vulnerable and existentially good (cf. Reitsma 1997:165). The agency of the Holy Spirit firmly unites quality and vulnerability, flourishing and suffering, in such a way that these two conditions cannot be separated from one another. In other words, through the work of the Spirit every living being is invited to accept the experience of vulnerability and finality of life. And denial of vulnerability may be interpreted as denial of the Spirit's 
creation, because creaturely life is supposed to be vulnerable, finite, and restricted. ${ }^{2}$ It is precisely in the finality, contingency and vulnerability that the quality of life emerges.

\section{Jürgen Moltmann on Spirit and vulnerability}

The Reformed theologian Jürgen Moltmann is widely characterized as one of the most productive and creative contemporary theologians. His theology has guided many people to new ways of thinking. In this section, I will focus on just a tiny part of Moltmann's pneumatology, which permeates his overall theology, and which is also specifically addressed in God in Creation (1985) and The Spirit of Life (1992). The intention here is to explore specifically Moltmann's perspective on the Spirit and vulnerability, since he is one of the very few theologians who address the theme of vulnerability (and disability) in relation to the work of the Holy Spirit.

Moltmann's theology of the Holy Spirit reveals a clear emphasis on the quality of creation. The purpose of creation, according to Moltmann (1985:64; 1992:31-38), is becoming God's home, where God's indwelling involves all of creation, not only human life. The homecoming in creation is the work of the Spirit. According to Moltmann, the Spirit dwells in creation (in its totality as well as in individual living beings) with the power of life. The understanding of the cosmic breadth of the Spirit is closely linked with the idea that creation is destined to become God's dwelling place. The eschatological condition of creation is the hope that inspires the current condition of creation: in the cross of Christ, the Spirit is committed to the historical condition of this world, where the Spirit displays the power of life that points toward the restoration and the affirmation of creaturely existence.

The future of creation requires an attitude of affirmation and sanctification of life. Moltmann's emphasis on the reverence of the life of all living creatures is about the retrieval of the holiness of life by respecting it, particularly life that is perceived as weak and insignificant. It is also about accepting the boundaries of life, rejection of violence pertaining to life, and the quest for harmony and balance. Reverence for life hinges on the themes of creation and re-creation: any form of life is holy because it is created by God and is desired by God for his coming inhabitation (1992:178).

2 Restrictedness should be understood as bound to the quantity of life, not as a reduction in quality of life. Any form of life that is called by the Creator Spirit, is final. Embodied life is restricted life by necessity, since life owes its value to its restrictedness. If there were no boundaries to human life, life would lose its value and its quality. 
The Spirit of life is the love between the Father and the Son in the cross event. ${ }^{3}$ This divine love assumes and embraces all life, and that applies also to forms of life that we usually exclude on the basis of weakness and disability. Moltmann (1992:193, italics original) emphasizes that the charismatic and healing powers of life also apply to inflicted life: "we have to recognize that every handicap is an endowment too. The strength of Christ is also powerful in the disablement." The Spirit of life, who is the Spirit of Christ, bequeaths every form of life with gifts that ought to be lived out in the service of the kingdom. This is what Moltmann (1992:182) labels 'the calling' of every living being: "when a person is called, whatever he is and brings with him becomes a charisma through his calling, since it is accepted by the Spirit and put at the service of the kingdom of God". Those who are physically or mentally impaired, ill, infected, or subordinated, are also called to the service of God's kingdom. Moreover, in the pains and disabilities they suffer, they reveal the suffering power of the God who relates himself to the weak with his own broken and humiliated body.

Moltmann (1992:190) also addresses the vulnerable human body when he says that the Spirit is "a living energy that interpenetrates the bodies of men and women and drives out the germs of death". The relation between the Holy Spirit and human body is expressed in the transfiguration of the body in this life. With the transfiguration of the body he means the change and the transit invoked by the Spirit of Christ, who is the Spirit of the resurrection of the dead. The Spirit embraces embodied life with the love of God, and places life in a new perspective. The Holy Spirit regenerates human life, gives new opportunities to mortal bodies, and invites man to look forward. The direction is the future, and the process toward vitality is rooted in God's eternal love that transfigures the body. In his Gifford lectures (1984/1985) Moltmann explains that vitality and vulnerability are about one's attitude that reveals one's humanity. It is the power of the soul to deal with the difficulties and afflictions in life; it is the strength to live, to suffer, and even to die. Therefore, vitality (or 'true health' as Moltmann also calls it) is attainable for anybody, regardless of age, presence of disease or other kinds of disabilities, because it is grounded in the affirmation of life, in the will to live in the light of hope.

All in all, Moltmann's pneumatology offers a fresh perspective on the relationship between creation and vulnerability. Moltmann constructs a strong link between the

3 In Moltmann's theology, the cross event is fully Trinitarian. The Son's utter isolation and the Father's mourning are embraced and translated by the Spirit into a history of surrender and love. The Holy Spirit is present in the cross, thus identifying with the suffering of the Son, even though the suffering of the Spirit is not the same as the Son's suffering. In the cross event, the Spirit becomes the love between the Father and the Son. This love generates life and brings life closer to its purpose. 
work of the Holy Spirit and the condition of creation by showing that the vulnerability of the triune God and the vulnerability of creation are joined in the love that is the Holy Spirit. The loving God assumes the vulnerability of creation. Moltmann attributes a notion of responsibility to vulnerability when he refers to vulnerable life as life that is called to renewal by the Holy Spirit. The call of vulnerable life includes the disabled and the outcast of society. They, too, receive the call and the responsibility in life that is endowed and renewed by the Holy Spirit. It is not very clear how the calling and its practices materialize in light of the coming kingdom. Moltmann mentions the transformation of the vulnerable body by the work of the Holy Spirit, but he does not substantiate how this transformation takes shape in the process of the Spirit drawing creation closer to God's kingdom.

\section{SPIRIT, VULNERABILITY AND BEAUTY}

Crucial to Moltmann's understanding of Spirit and vulnerable creation is the close arrangement of quality and vulnerability by the work of the Holy Spirit. I will follow this path, considering what this pairing of quality and vulnerability means for human life.

\section{Vulnerability dialectics}

On the basis of constructive approaches to vulnerability, and considering Moltmann's pneumatological understanding of vulnerability, one could say that the Spirit of God introduces vulnerability as a qualification of the relation between a loving God and his creation. Vulnerability not only means that creaturely life is receptive to damage and disappointment. It also means that one can find particular quality in the experience of vulnerability. Vulnerability is the capability to be kept safe and whole, to be healed and lifted. This vulnerability, which becomes most tangible in the sensitive human body, turns out to be a quality under the reign of the Holy Spirit.

The pairing of vulnerability and quality is framed by the idea that vulnerability is the realm of the Spirit. Where the Spirit is at work, vulnerability means susceptibility to love and mercy. That is because the Holy Spirit puts human life in touch with cross and resurrection of Christ. Creation needs the Spirit to see the depth of the cross, and to be introduced to the impaired, crucified Christ who demonstrates a new understanding of vulnerability. The wounds of Christ's body undermine our illusion of auto-salvation and they deconstruct our cult of normalcy. Seeing the depth of the cross, thanks to the Spirit, means responding to the scandal of vulnerability. It involves nailing one's ideas about vitality to the cross, surrendering one's strategies of power, and betraying one's own understanding of what is normal. The Spirit of 
the incarnated God creates a relationship between the cruciform death of Christ and the cruciform experiences of human life, for the sake of gracing our vulnerable life and maintaining the quality of creation. Through the cross of Christ, the Holy Spirit reveals the truth about God's love for creation and about its God-given quality. Moltmann (1992:64) convincingly explains that the story of the suffering of the Son is the story of the suffering of God's Spirit as well. However, "the Spirit does not suffer in the same way, for he is Jesus' strength in suffering, and is even the 'indestructible life' in whose power Jesus can give himself vicariously 'for many'".

The Spirit aims to transform vulnerable afflicted life into vulnerable restored life. It does not mean that the Spirit turns affliction and evil into something smooth and positive. The Spirit does not 'fix' life by re-establishing the former condition of life, just as the Spirit did not reverse or negate the wounds and scars of Jesus' body after the cross. Instead, the vulnerable and broken body of Christ is included in his resurrection. The glorified body is a site of deep wounds, because this is how God reveals himself: He is the Lord of life who endows vulnerable life with resurrection quality, with an inclination towards glory, love and reverence. Resurrection of vulnerable life does not imply the move from vulnerability to invulnerability but the transformation from damaged vulnerability into restored vulnerability through God's love and grace. Human life will always remain vulnerable. But by being in the realm of the Spirit, vulnerability draws us into an intensity of life that makes us search for earnest ways of being who we are.

When the Spirit nudges us into accepting our vulnerability as part of life that belongs to a vulnerable God, the Spirit retrieves the quality of life that is bestowed upon creation. But it is not a plain, effortless quality. It involves a vulnerability dialectics of cross and resurrection, of being wounded and being raised, of affliction and restoration. This dialectics, which means that one cannot speak of vulnerability without using both words, emphasizes the complexity of vulnerability. It is not only about the attitude of openness or the effort of being in relationship at the risk of being hurt. It is also about claiming the wounds of fear, rejection and failure that are part of us, perhaps just as Jesus claimed his wounds when He revealed himself to his disciple Thomas. Nancy Eiesland (1994:101) says that the resurrected Christ with his impaired hands and feet transforms the taboos surrounding vulnerability and disability of the body, and links them closely to new abilities. Daniel Louw (2008:100) even states that in the disfigurement of the resurrected Christ a new theological model of wholeness and a metaphor for life within disfigurement can be discerned. The new hermeneutics of vulnerable life is thus a discontinuous continuity, because vulnerable life is now considered as life that belongs to God who has bound death, and at the same time has bound life by death. 


\section{Vulnerability as beauty}

The vulnerability dialectics of surrendering and claiming describes human life in the presence of the Spirit. Patrick Sherry (2007:12f) relates the presence of the Spirit to the notion of beauty, because 'beauty' will help us to understand how God reaches out to his creation through the Holy Spirit.

Beauty may refer to notions such as excellence, glory, symmetry, proportion, harmony, consent, union, love and holiness (see Venter 2010:187). This perspective has been developed by Jonathan Edwards, who viewed the triune God as a society of love and beauty. Creation, all beauty in creation, may be perceived as the overflow of inner-trinitarian beauty that is communicated by the Holy Spirit. The Holy Spirit is God's infinite beauty, "and this is God's infinite consent to being in general" (Edwards, "The Mind", entry 45) so that the very structure of being can also be understood as beauty. This idea of divine beauty as the archetype of earthly beauty can also be found in the writings of the Cappadocians, Augustine, Karl Barth and Hans Urs von Balthasar.

Von Balthasar (1982:124) developed the idea that the Christian understanding of beauty hinges on the ugliness of the cross: the ugliness of the cross is the utter denial of God's glory and the destruction of God-given life. Yet this revolting cross event discloses God's love for creation, and it reveals His beauty and inclination to perfection of life. Viladesau (2008:186) says, "Christ - precisely on the cross - is the supreme revelation of God's being, God's form, glory, and beauty".

The Holy Spirit, who is the beauty of God and who is present with Christ in the ugliness of the cross, produces a redefinition of beauty. In the realm of the Spirit beauty no longer means absence of ugliness. The Holy Spirit did not obscure or deny the wounds of Christ's body, but instead taught him to claim his wounds and brokenness. God's Spirit, as divine infinite beauty, thus assumes ugliness in such a way that glory and delight prevail. Rather than rejecting everything that does not exemplify God's beauty, the Holy Spirit chooses to redefine God's beauty itself. Instead of understanding damage and ugliness as conditions that do not correspond with beauty, beauty itself is transformed and opened up so that the Holy Spirit still can communicate God's life in creation. God's life of beauty and glory now engages the opposite, the presence of suffering, and the complex condition of vulnerability. In other words, under the reign of the Holy Spirit, who beautifies all things, we may learn to live with a converted sense of beauty.

This converted sense of beauty brings forth the understanding that the Holy Spirit beautifies our vulnerability by assuming both our being wounded and our being raised. Just as the Holy Spirit was present in the disfiguration and in the 
transfiguration (beautification) of Christ's body, so the Spirit repetitiously is present with each form of vulnerable life. In the realm of the Holy Spirit, life turns out to be a discontinuous continuity: our vulnerable life is drawn in the beauty of God's life through the ugliness of the cross.

Our vulnerable life thus becomes beautiful life when we embrace our existential condition in the sense that we consent to being vulnerable. This consent to being vulnerable does not imply that we acceptingly endure our vulnerable and finite condition as if that is the only way to approach vulnerability. Vulnerability is a discontinuous continuity with the promise of beauty. Vulnerable life becomes beautiful life when we move with the Spirit and learn to see that human life is meant to be vulnerable and limited. Because in the vulnerability and finiteness lies the quality of life through which God is glorified. In other words, if life would be invulnerable and boundless, then life would lose its meaning and quality. It would be life outside the realm of the Spirit, the creating life-giving breath of God.

The redefinition of vulnerability by the work of the Holy Spirit is thus an invitation to human beings to own their vulnerability, to consent to being susceptible to wounds as well to wholeness. The embrace of vulnerability means involvement in the Spirit's mission of beautifying creation, because accepting vulnerability is an act of beautifying life - my own life and the life of others.

The pneumatological perspective on vulnerability as redefined beauty, as beauty that is touched by ugliness, emphasizes that vulnerability is a multi-layered concept that carries notions of openness, hospitality, reverence for life, resistance of the cult of normalcy, of joy and gratitude. Yet in relation to the work of the Holy Spirit, vulnerability also includes a sense of danger - not in the 'traditional' sense that vulnerability means the danger of being wounded, for that is a definition of the cult of normalcy. But way beyond that traditional definition the Spirit teaches us that vulnerability means the danger of losing oneself, of being drawn out of one's own comfort zone in order to comfort others in the name of the Father, the Son and the Holy Spirit. It is the gracious work of the Spirit, who challenges the idea that our human life should be defined by strength or influence, or be shielded from risk and frailty. When feeling weak and wounded, we simply want our strength to be restored. But the Spirit wants our identity to be restored. The Holy Spirit teaches us a dangerous thing: our true identity does not depend on human capacities, but on God's grace and beauty. 


\section{CONCLUSIONS}

The growing body of theological voices, aiming at resisting the commonly defined, negative interpretation of vulnerability, necessitates the exploration of new understandings of human vulnerability. Four particular voices of Reformed theologians (Placher, Jensen, Reynolds, Culp) have been discussed here. Dismissing the understanding of vulnerability as an undesirable condition of life, these voices claim that vulnerable life is always complex, ambiguous and multi-layered, since it is life that is influenced by God's own intricate vulnerability. These constructive proposals show that it is an illusion to refer to vulnerability as a simple and straightforward condition of life, whether aspired or not.

Despite the emergent contributions to the discourse of vulnerability, there is still need for pneumatological explorations of vulnerability in order to broaden vulnerability hermeneutics. Jürgen Moltmann is one of the very few theologians who explicitly address the theme of vulnerability in relation to the work of the Holy Spirit.

Moltmann's close arrangement of the notion of quality (of creational life) and vulnerability through the work of the Spirit allows for additional constructive ideas: (1) vulnerability may be seen as the realm of the Spirit, (2) vulnerability as a quality under the reign of the Spirit involves a vulnerability dialectics of cross and resurrection, of affliction and restoration, (3) the Spirit, who is the beauty of God and who is present with Christ in the ugliness of the cross, produces a redefinition of beauty. Through the work of the Spirit vulnerable life becomes beautiful life (in its converted sense) when we move with the Spirit and consent to being vulnerable. Embracing vulnerability is thus an act of beautifying life.

\section{BIBLIOGRAPHY}

Berinyuu, A 2004. Healing and Disability. International Journal of Practical Theology, 8(2):202-211.

Bonhoeffer, D 1972. Letters and Papers from Prison. Translated Reginald H Fuller et al. New York: MacMillan Publishing Co.

Culp, KA 2010. Vulnerability and Glory: A Theological Account. Louisville: Westminster John Knox Press.

Dube, MW 2002. Theological Challenges: Proclaiming the Fullness of Life in the HIV/AIDS \& Global Economic Era. International Review of Mission, 91(363):535-550. 
--- 2004. "Grant me Justice: Towards Gender-Sensitive Multi-sectoral HIV/ AIDS Readings of the Bible", in Dube, MW \& Kanyoro, M (eds). Grant me Justice! HIV/AIDS \& Gender Readings of the Bible. Pietermaritzburg: Clusters Publications. 3-24.

Edwards, "The Mind", entry 45, The Works of Jonathan Edwards, with a memoir by Sereno E. Dwight, edited by Edward Hickman, 2 vols. Reprint edition, Edinburgh: Banner of Truth Trust, 1979. 1.cccxxxi

Eiesland, NL 1994. The Disabled God: Toward a Liberatory Theology of Disability. Nashville: Abingdon Press.

Isherwood, L \& Stuart, E 1998. Introducing Body Theology. Sheffield: Sheffield Academic Press.

Jensen, DH 2005. Graced Vulnerability: A Theology of Childhood. Cleveland: Pilgrim Press.

Louw, DJ 2008. Cura Vitae. Illness and the healing of life. A guide for caregivers. Wellington: Lux Verbi.

Koopman, N 2008. Vulnerable Church in a Vulnerable World? Towards an Ecclesiology of Vulnerability. Journal of Reformed Theology, 2(3):240-254.

Meylahn, J-A 2012. The folly of vulnerability beyond epistemic injustice and the power of knowledge: A vulnerable praxis of thinking (practical theological ethos) in global conversation. Theological Studies, 68(2). Article \#1304, 5 pages. [Online]. Available: http://dx.doi.org/10.4102/hts.v68i2.1304 [2014, 3 January].

Moltmann, J 1985. God in Creation: A New Theology of Creation and the Spirit of God (The Gifford Lectures, 1984-1985). London: SCM Press.

--- 1992 [1991]. The Spirit of Life. A Universal Affirmation. Minneapolis: Fortress Press.

Moyaert, M 2012. On Vulnerability: Probing the Ethical Dimensions of Comparative Theology. Religions 3. 1144-1161. [Online]. Available: www.mdpi. com/2077-1444/3/4/1144/pdf [2013, 29 December].

Nelson, JB 1992. Body Theology. Louisville: Westminster/John Knox Press.

Placher, WC 1994. Narratives of a Vulnerable God. Christ, Theology, and Scripture. Louisville: Westminster John Knox Press. 
--- 1999. "The Vulnerability of God", in: Willis-Watkins, D, Welker, M \& Gockel, M (eds). Toward the Future of Reformed Theology: Tasks, Topics, Traditions. Grand Rapids: Eerdmans. 192-205.

Polkinghorne, JC 2006. “The Hidden Spirit and the Cosmos”, in Welker, M (ed). The Work of the Spirit. Pneumatology and Pentecostalism. Grand Rapids, Cambridge: William. B. Eerdmans Publishing Company. 169-182.

Reinders, HS 2000. The Future of the Disabled in Liberal Society. An Ethical Analysis. Notre Dame: University of Notre Dame Press.

Reitsma, BJG 1997. Geest en schepping. Een bijbels-theologische bijdrage aan de systematische doordenking van de verhouding van de Geest van God en de geschapen werkelijkheid. Zoetermeer: Uitgeverij Boekencentrum.

Reynolds, TE 2008. Vulnerable Communion. A Theology of Disability and Hospitality. Grand Rapids: Brazos Press.

Rieger, J 2001. God and the Excluded. Visions and Blind Spots in Contemporary Theology. Minneapolis: Fortress Press.

--- 2007. Christ and Empire. From Paul to Postcolonial Times. Minneapolis: Fortress Press.

Rogers Jr, EF 2005. After the Spirit. A Constructive Pneumatology from Resources outside the Modern West. Grand Rapids: Eerdmans.

Sherry, P 2007. The Beauty of God the Holy Spirit. Theology Today, 64:5-13.

Snyman, G 2011. Empire and a hermeneutics of vulnerability. Studia Historiae Ecclesiasticae, 37(supplement):1-20.

Taylor, JV 1972. The Go-Between God. London: SCM.

Van Niekerk, PI 2012. Towards a Theology of the Body. A Spirituality of Imperfection. NGTT, 53(3 and 4): 369-375. [Online]. Available: ngtt.journals. ac.za/pub/article/viewFile/275/386 [2013, 29 December].

Venter, R 2010. Trinity and beauty: The theological contribution of Jonathan Edwards. NGTT, 51(3 \& 4):185-192.

Viladesau, R 2008. Theosis and Beauty. Theology Today, 65:180-190.

Von Balthasar, HU 1982. The Glory of the Lord: A Theological Aesthetics, volume 1, Seeing the Form. San Fransisco: Ignatius. 
West, GO 2003. Reading the Bible in the Light of HIV/AIDS in South Africa. Ecumenical Review, 55(4):335-344.

--- 2004. Reading Job "Positively" in the Context of HIV/AIDS in South Africa. Concilium, 4:112-124.

West, GO \& B. Zengele 2006. The Medicine of God's Word: What People Living with HIV and Aids Want (and Get) from the Bible. Journal of Theology for Southern Africa, 125:51-63.

Yong, A 2007. Theology and Down Syndrome. Reimagining Disability in Late Modernity. Waco: Baylor University Press.

--- 2008. Hospitality and the Other. Pentecost, Christian Practices, and the Neighbor. Maryknoll: Orbis Books. 
